\title{
Abstract \\ Detection of Biogenic Amines in Canned Tuna Using a Voltammetric Electronic Tongue ${ }^{\dagger}$
}

\author{
Marta Bonet-San-Emeterio (D), Maria Bruguera-Jané, Xavier Cetó and Manel del Valle *(D)
}

check for

updates

Citation: Bonet-San-Emeterio, M.; Bruguera-Jané, M.; Cetó, X.; del Valle, M. Detection of Biogenic Amines in Canned Tuna Using a Voltammetric Electronic Tongue. Eng. Proc. 2021, 6, 41. https://doi.org/10.3390/ I3S2021Dresden-10169

Academic Editors: Gianaurelio

Cuniberti and Larysa Baraban

Published: 21 May 2021

Publisher's Note: MDPI stays neutral with regard to jurisdictional claims in published maps and institutional affiliations.

Copyright: (c) 2021 by the authors. Licensee MDPI, Basel, Switzerland. This article is an open access article distributed under the terms and conditions of the Creative Commons Attribution (CC BY) license (https:// creativecommons.org/licenses/by/ $4.0 /)$.
Sensors and Biosensors Group, Chemistry Department, Universitat Autònoma de Barcelona, 08193 Bellaterra, Spain; marta.bonet@uab.cat (M.B.-S.-E.); maria.brugueraj@e-campus.uab.cat (M.B.-J.); xavier.ceto@uab.es (X.C.)

* Correspondence: manel.delvalle@uab.cat

+ Presented at the 8th International Symposium on Sensor Science, 17-28 May 2021; Available online: https://i3s2021dresden.sciforum.net/.

\begin{abstract}
Biogenic amines (BAs), which are produced naturally due to the decomposition of amino acids, are crucial for the food industry because its formation is directly related to improper storage and the presence of bacteria. High concentrations of BAs can be easily related with the quality and spoilage of the products of this sector. The necessity to quickly and efficiently quantify these targets makes mandatory the use of alternatives to conventional analytical methods used up to now. For example, the combination of sensors with chemometric tools (known as electronic tongue) are a promising alternative for quick and informative analysis in the food sector. Chemometric tools allow us to develop models for the quantification of specific compounds in a complex matrix, making it a feasible tool for the development of more user-friendly methods than the traditional ones. In this context, the work presents an electronic tongue created for the detection of histamine, cadaverine and tyramine using a set of five modified GEC (graphite epoxy composite) electrodes: ZnO NPs, $\mathrm{CuO} \mathrm{NPs}, \mathrm{SnO}_{2} \mathrm{NPs}, \mathrm{Bi}_{2} \mathrm{O}_{3} \mathrm{NPs}$, and polypyrrole, as the voltammetric multisensor array. The chemometric model was obtained with an Artificial Neural Network (ANN) with 51 input neurons, five neurons in the hidden layer and three neurons in the output layer. The functions used for the hidden and output layers were tansig and purelin, respectively. The results show slopes near to 1 and intercepts close to 0 , indicating the feasibility of the model.
\end{abstract}

Keywords: artificial neural networks; electronic tongue; biogenic amines; histamine; voltammetry

Institutional Review Board Statement: Not applicable.

Informed Consent Statement: Not applicable.

Data Availability Statement: Not applicable. 